\title{
Disruptive Dialogics: Improvised Dissonance in Thelonious Monk and Wu-Tang Clan's 36 Chambers
}

\author{
Paul Watkins
}

Popular music is nothing if not dialogic, the product of an ongoing historical conversation in which no one has the first or the last word. The traces of the past that pervade the popular music of the present amount to more than mere chance [. . .] they reflect a dialogic process, one embedded in collective history and nurtured by the ingenuity of artists interested in fashioning icons of opposition. (George Lipsitz, Time Passages 99)

\section{Streaming audio of "(re)vision \& the abstract truth"1}

The current paper, “Disruptive Dialogics: Improvised Dissonance in Thelonious Monk and Wu-Tang Clan's 36 Chambers," in its juvenile stage, was performed with the aid of a sampler (MPC 1000) at the 2010 Guelph Jazz Festival Colloquium. The performative paper opened with a spoken word poem, "(re)vision \& the abstract truth" and was underscored by cued "live" samples from multiple critical jazz performances. The talk tracked "flow, layering, and rupture" in Hip Hop performance. This poem, in its rerecording, provides some context to how the paper initially sounded when performed live. The poem, "(re)vision and the abstract truth," sonically samples (perhaps "steals" a moment from) "Stolen Moments" from Oliver Nelson's The Blues and the Abstract Truth; hopefully, it also enacts some of the musical dialogism and rupture the paper engages in. Simply put, the poem, which is drawn from my own listening praxis, provides one "version" of the multilayered, polysemic endeavor that comes with critically reflective sampling practices. It is an ode to some of the best listeners and improvisers, as well as an investigation of those valuable moments where fragmentation, or rupture, becomes the poetic act itself.

\section{The dialogic jazz sample: flow, layering, and rupture in Hip Hop}

As George Lipsitz argues, the past has a direct relation to the present in popular music, one which is particularly played out and incorporated in the sampling culture of Hip Hop, ${ }^{2}$ which often integrates blues, jazz, and funk in its sounding a space of opposition. Through such bricolage, vis-à-vis a syncretic sounding of what could arguably be described as disparate sounds, Hip Hop actively participates in the dialogic and polyphonic tradition that literary theorist Mikhail Bakhtin outlines in his work on the novel. Bakhtin argues compellingly that all utterances respond to something that was said before, that often the speech composed by a single speaker "actually contains mixed within it two utterances, two speech manners, two styles, two languages, two semantic and axiological systems" (Dialogic 304). Under Bakhtin's speech-model, Hip Hop is polyphonic: composed from at least two axiological systems, inviting, as most musical or literary performances do, polysemic interpretations from its readers. Further, Hip Hop's chronotopal (another word from Bakhtin connoting "time-space") weaving in and out of diachronic and synchronic temporalities creates flow and fluidity between traditions of the past (blues and jazz for instance) and the present musical and social landscape-enacting a layering of multiple samples, voices, genres, and instrumentations in dialogue - while employing rupture to create disruption, yet dialogic potentiality.

It might seem a little strange to apply a literary and linguistic framework, albeit a dialogic and open one, in a musical context; however, assuming that a methodological lens is not applicable to such a model denies the simultaneously iterative, yet disjunctive, as well as resistive and libratory, potentials of an improvisation that functions across boundaries. Similarly, our understanding of writing as a static and heavily mediated activity needs to be challenged, to be seen as more mutable-like musical improvisation. ${ }^{3}$ Analogously, a recorded song is not limited by any single recorded version, as evidenced in many genres including jazz, blues, rap, r\&b, reggae, calypso, soca, salsa, AfroCuban, and dub, in which you can find multiple versions of a song on a particular twelve-inch: a cappella, instrumental, and so on. Dick Hebdige explicates that it is the Jamaican concept of "versioning," described as a type of democratic revisioning, which is at the heart of all African American and Caribbean music: "They're just different kinds of quotation. And that's the beauty, too, of versioning. It's a democratic principle because it implies that no one has the final say. Everybody has a chance to make a contribution" (Cut n' Mix xv). Besides, jazz, given the exigency of the political, cultural and sonic soundscape from which it was dialogically shaped, does not typically enact a clear division between musical categories. For example, Charles Mingus' "Pithecanthropus Erectus" is a meshing of sumptuous and disparate sounds, from a variety of intertexts, which is rich in sonic adventurism: it builds dialogically upon Duke Ellington's own tone poems, as well as flaunting and reappropriating classical norms (and cultural contexts), while also sounding its own unique modernism. In fact, most exciting and politically endued jazz or Hip Hop draws from, appropriates, and recontextualizes a variety of forms to create a syncretic sounding that challenges any single referentiality, repeating a tradition with difference. In this way jazz is a multilayered, polysemic endeavor that 
improvises by playing something new over a shared standard, much in the same way that Hip Hop dialogically draws upon the diverse past of blues, jazz, and funk, among a plethora of other resources, enacting a layering that uniquely - with repetition and difference — sounds its own resistance to create a distinctive sonic space.

In The Signifying Monkey, Henry Louis Gates Jr. notes: "Repetition of a form and then inversion of the same through a process of variation is central to jazz" (104). Further, as Jeffrey T. Nealon argues in his article "Refraining, Becoming Black": "African-American traditions have deployed 'repetition with a difference' as a key concept in maintaining a vibrant culture on the margins of the American mainstream" (83). In this way, I argue that Hip Hop enacts repetition with a difference, improvising upon a standard in an iterative, yet distinctively unique, although not separate, context from live jazz. For Hip Hop producers, DJs, and electronic artists, the recorded medium is often the archive. However, this archive is not stagnant; rather (in relation to "versioning"), anyone can remix, remake, and reedit a piece of record history. In "Improvising Digital Culture," a conversation between Paul D. Miller (aka DJ Spooky) and Vijay lyer, Miller polemically states that "The whole notion of hip hop as 'not live' is very problematic." Miller describes that "when [he] was coming up on the scene, there was a lot of beef between the older jazz musicians and younger hip hop kids. In fact, I was one of the first DJs to work with Amiri Baraka, and he [would say things like,] 'You know, Paul, this hip hop's OK, but why's it always repeatin'?' It's a valid question." As Miller states, it is a valid question, but it is also problematic to assume that there is no variation (or improvisation) with difference in sample based Hip Hop music.

As Alexander G. Weheliye contends, even repetition with difference might be more difference than repetition: "difference will, indeed, be different in each of its incarnations" (32), suggesting "not repetition with a difference so much as repetition of difference, wherein the original/copy vanishes" (32) so that only the sui generis of the original remains. As James Snead argues relative to repetition, the "cut" in jazz, where the improvising soloist departs from the 'head' or theme of the harmonic sequence or from the familiar beat, is performed only in dialogism with the other forces at play in the piece, functioning as the difference in the repetition ("Repetition" 69). It is precisely these types of breaks, the sustained rhythmic ones in particular, that Weheliye describes, and that I would also identify, "as the building blocks for the whole genre of hip-hop, in which DJs or producers isolate these moments to mechanically repeat (loop) them as the basis for wholly new tracks" (64). ${ }^{4}$ Hip Hop music, and DJ culture generally, has a lot to do with taking found objects and sounds, looping them, and placing these constitutive elements alongside each other by way of flow and layering, rupturing the past into an anachronistic, yet cohesive present.

The notion of "flow, layering and ruptures in line" (38) is outlined by Hip Hop scholar Tricia Rose in her seminal book Black Noise: essentially, Rose argues that in Hip Hop the visual, physical, musical, and lyrical lines are set in motion and broken abruptly with sharp angular breaks, yet they sustain motion and energy through fluidity and flow. Rose describes how "rappers speak of flow explicitly in lyrics, referring to an ability to move easily and powerfully through complex lyrics as well as of the flow in music" (39). We can think of flow and layering as a type of weaving or rhapsodizing. To rhapsodize means "to stitch songs together," something DJs do literally when they incorporate a multitude of samples into a single production; however, the more rupturing or polyphonically disruptive the effects of such productions are, the more often such productions have historically been interpreted, often by white critics and listeners, as noise. ${ }^{5}$ Rose describes Hip Hop, and music in general, as organized noise, arguing that "orally based approaches to narrative are embedded in the use of technology itself" (64). Robert Walser contributes to Rose's defense of Black noise by suggesting that "the noisiness of hip hop contributes to its ability to express dissent and critique, and to articulate the identity of a community that is defined as, or that defines itself as, noise" ("Rhyme" 198). ${ }^{6}$ For example, to the untrained listener Public Enemy's song "Night of the Living Baseheads" might be perceived simply as noise; however, it is a highly structured noise-with nearly 45 samples in addition to the basic rhythm tracks and original music which coexist on another 24 tracks, in total there are nearly one hundred tracks layered in this one song (Rose, Noise 80). RZA, the key producer and founder of the Wu-Tang Clan, suggests that "Music only needs a pulse. Even a hum, with a bass and a snare-it'll force a pulse, a beat. It makes order out of noise. It'll work with anything, I mean anything" (204). Similarly, Thelonious Monk summed up his music by saying that it was about how "to use notes differently" (Live, liner notes). Layering, as difference, which we can call interpretive sampling (although some critics and corporations prefer the term stealing) has been a staple in jazz's reinterpretive practice of making something new out of the old long before Hip Hop ever came along. We can hear this absorption of the old into the new in Nina Simone's interpolation of the Christmas carol, "Good King Wenceslas" into a counter melody for her version of "Little Girl Blue." Appropriation is turned on its head vis-à-vis "versioning" (borrowing from Jamaican music), where sampling, borrowing and re/appropriation is the central aesthetic.

I argue that under this model, music that samples or reinterprets an original, can be viewed as a cultural tactic that represents an African American continuum-essentially an acknowledgment of self-consciousness and empowerment in the face of hegemonic superstructures that attempt to control, market, codify and silence Black performers through strict copyright laws. Further, sampling, or reinterpretive poetics-from sampling from a musical archive to reinterpreting a prior recording — creates a dialogue between the original recording (although as Bakhtin 
mentions everything we create is no more than half ours) and its new context. Additionally, polyphonic dialogism that is improvisationally disruptive with the intention to reform and rethink structure has an inherent pedagogical framework built into it, particularly when the sampling is used as a direct and antiphonic invocation to a larger marginalized community. In challenging hegemonic recording industries and societies, ${ }^{7}$ reinterpretation and tactical sampling ${ }^{8}$ by musicians can function as a prefiguring of imaginative possibilities for a better future; as bell hooks argues: "African American performance has been a site for the imagination of future possibilities" ("Performance Practice" 220). The use of a sample, such as Public Enemy's weaving of a Khalid Abdul Muhammad (onetime Louis Farrakhan protégé) vocal clip into the introduction of "Baseheads," creates both flow and rupture to create a disruptive poetics that challenges standard Western harmonic listening approaches vis-à-vis what can be called dissonant politics. The dialogically dissonant is not necessarily alienating; it is not monologic, but is rather antiphonic in that it draws upon the past as a reference that responds to a shifting, and often still oppressive, present. A single jazz recording is not limited by that sole performance, as DJs and musicians alike continue to dig through the archives of the past, responding to the demands of the present. In looking at the improvisatory style of Thelonious Monk, ${ }^{9}$ which reinterprets a jazz tradition with a sense of dissonant freedom, and then by looking at how the Hip Hop group Wu-Tang Clan incorporates, samples and interprets Monk's stylized playing and persona in their song, "Shame on a Nigga" (from 36 Chambers), we can explore how sampling participates in a dialogic continuum that promotes agency, recognition, community and mobility.

\section{Monk's dissonant and embodied poetics}

Monk's unique and highly self-conscious mode of playing, as well as his idiosyncratic behaviour (which I see as unique, rather than aberrant) - from his dancing during live performances, to his vast array of hats-has made him one the most attractive figures in the history of jazz-related music and poetry. ${ }^{10}$ His song "Round Midnight" is, according to the allmusic website, the most covered jazz song in history (cited on allmusic as appearing in over a 1000 albums), ranging from covers by artists such as Miles Davis to loose adaptations by avant-garde musicians such as The Art Ensemble of Chicago. A 1948 review of Monk's now uber-famous "Round Midnight" in Down Beat magazine describes the song as "for the super hip alone" (19), and gave it a mere two out of four stars for what has surely become one of jazz's most recognizable manifestos. Gabriel Solis describes that what is interesting about a song such as "Round Midnight" is the panoply of voices associated with it- "Monk's, the current performer's, and those of its various interpreters through time" (105). Miles Davis's version has become perhaps even more popular than Monk's original, but Davis, as Robin D.G. Kelley argues, had great respect for Monk's composition, believing that "'Round Midnight" was "as challenging as anything Ravel, Schoenberg, or Bach had to offer" (106). Under this rubric, Monk's music can be viewed as a cultural source that represents an African American mood, essentially an antiphonic counterpoint with which other jazz players or Hip Hop artists can directly dialogue in their own playing and representations of space. "'Round Midnight" provides a salient example of how a standard is open to constant, often mutable, interpretation via the multiple "versionings" and unique improvisations that particular jazz composition has undergone since its inception.

Thelonious Sphere Monk was born in Rocky Mount, North Carolina, in 1917, and by 1940 he was working with the major jazz figures of his time. Monk is said to have started playing his style of jazz in the early forties, when he played piano at Minton's in Harlem. In '47 he recorded sessions for Blue Note records that placed him at the epicenter of modern jazz: such attention also exposed his unique mode of playing jazz to an antagonistic sphere of criticism, where his flouting of classical and jazz norms was described by critics, and particularly white listeners, as ineptitude rather than innovation. For example, Monk's initial recordings for Blue Note sold poorly, and the label's owner, Alfred Lion, reported that white listeners thought the pianist "lacked technique" (qtd. in Nat Hentoff 196). However, he did have his supporters. Mary Lou Williams, an early mentor and friend of Monk, describes Monk's music as Zombie music. Zombie music, she said, "Because the screwy chords reminded us of music from Frankenstein or any horror film" (qtd. in Van der Bliek 12). Dialogically interpreting Monk's playing within a sphere of monstrosity, as 'screwy,' and along an axis of alterity demonstrates how and why Monk has been viewed as an improviser who uniquely defines his own marginalized style in relation to others. Monk has been, and still is, often described vis-à-vis an endless string of epithets: as nonconformist, idiosyncratic, imaginative, eccentric, and, most commonly, unique. ${ }^{11}$

In 1964, Monk became the third jazz musician to have his portrait on the cover of Time magazine, after Duke Ellington and Dave Brubeck. ${ }^{12}$ The Time article stated, "Aside from his hat and the incessant shuffle of his feet, he looks like a perfectly normal neurotic" (3). The paradoxical description in Time of Monk's normalized neurosis signals that Monk is often, and probably intended to be, viewed as atypical: as a source of undefined imaginative possibility, someone whose pianism or peculiar style cannot be easily appropriated. Further, while the Time article does acknowledge Monk's unique presence upon the world of jazz, as well as the difficulty in appropriating his technique, saying that "Monk's style is so obviously his own that to imitate it would be as risky and embarrassing as affecting a Chinese accent when ordering chop suey" (8), the article also reinforces a subversive marginalization that segregates Monk from an authoritative centre. By marginalizing Monk's music as different, avoiding how it could be used as a 
potentially viable pedagogical framework for innovative creation, Time further polarizes Monk as someone who is creative and unique but perhaps unworthy of imitation, of changing our approaches to the harmonic lexicon of Western pianism. As Gayatri Spivak argues, "When a cultural identity is thrust upon one because the centre wants an identifiable margin, claims for marginality assure validity from the centre" (Outside 55). Despite such difficulty, and given the fact that Monk's stylized playing is still often viewed as marginal, I make the argument that approximating Monk's style, or even his public persona, can be read as a negotiation of dissonance with the intention to disturb the naturalized order of knowledge production, thus creating a disruptive poetics that challenges hegemonic listening approaches to jazz and its dialogically intertwined manifestations.

Despite this inferred challenge to authority, it is important to note that Monk, in a comment he later regretted, articulated that his "music is not a social comment on discrimination or poverty or the like. I would have written the same way even if I had not been a Negro" (qtd. in Kelley 249). Kelley argues that what was clearly "a defense of artistry [was often turned] into a complete rejection of politics" (249). However, while Monk himself was not a particularly outspoken or a verbally political person (as watching or reading any of his interviews makes apparent), ${ }^{13}$ his use of dissonance and his often improvisatory mode of playing can be read as a disruptive poetics that recalls a larger tradition of Black innovation within a continuum of resistance. Nevertheless, rather than trying to understand the cultural contexts that produce and value dissonance as aesthetic evolution, many critics have historically expressed distaste for the dissonance commonly found in Bebop and Hip Hop music, labeling the music as "noise."14 In defending Monk's method of playing what was perceived as dissonant pianism, ${ }^{15}$ Michael James contends that the most effective of Monk's techniques is "his cunning use of dissonance which, despite the criticism it has often provoked, is never deployed without a valid aesthetic reason" (qtd. in Reader 137). In fact, as I hear it, with his style of broken rhythms, dense stripped-down chords, and creative use of silence, Monk's use of dissonance-Kelley argues that Monk was fond of "chromaticism, rhythmic displacement, and dissonance" (93)—emphasizes the rhythmic aspects of the music as much as the harmonic and melodic ones; as a result, his mode of playing challenges us to reconsider standard Western notions of harmony and melody.

While Monk was often criticized for his harsh and percussive approach to playing the piano, by critics such as Leonard Feather who described his playing as lacking "technique and continuity" (Inside Be-Bop 10), ${ }^{16}$ hitting the keys with fingers held flat rather than in a natural curve, he did have many ardent followers, such as Amiri Baraka (then LeRoi Jones) who, in a 1964 article for Down Beat, argued that Monk "can get around to any place on the piano he thinks he needs to be, and for sheer piano-lesson brilliance, he can rattle off arpeggios and brilliant sizzling runs that ought to make even those 'hundred finger' pianists take a very serious look" (qtd. in Van der Bliek 168). ${ }^{17}$ For evidence of this, one need only to watch the documentary film Straight, No Chaser that highlights just how much Monk's playing is an embodied experience: in the film's segment for "Just a Gigolo,"18 Monk's body jerks, his hands glide and dance around the keys with each percussive attack, as he struggles to articulate the embodied experience that animates his playing. The dissonance heard is really a rhythmic dissonance as Monk plays the piano as much like it's a percussive instrument as a melodic or harmonic one. What I am calling rhythmic dissonance-Monk's syncopated style of playing the piano-allows Monk to improvise with expressive tension, moving beyond dogmatic approaches that adhere to strict classically defined norms of rhythm and meter. ${ }^{19}$

In his article "Thelonious Monk's Pianism" for the Journal of Musicology, Benjamin Givan makes the case that Monk intentionally created technical hurdles for himself in order to imbue his playing with a degree of expressive tension. Monk apparently uses the crossed-hands technique for audible expressive reasons when it is neither physically advantageous in itself nor directly related to the music's pitch structure, as is clearly evidenced in the video recording of "Just a Gigolo," "Criss-Cross," and "Round Midnight." In creating these challenges, Monk forces himself to improvise, becoming the physical embodiment of spontaneity within the structure of a carefully calculated yet wellswung rhythm. Whether, as Monk's wife Nellie claimed, ${ }^{20}$ it was Monk's physical limitations (his height, posture, and small hands) that spurred his musical innovations, or whether those limitations reflect, as Givan argues, Monk's personal desire to "highlight the human mechanics of sound production" (428), Monk embodies the theatrical aspect of playing the piano in order to perform what it looks and sounds like to play the piano on your own terms, often with melodic lines that were decisively non-legatto and expressively dissonant. Thus Monk, as performer, as public persona, and as pianist extraordinaire, coalescences into the physical embodiment of spontaneity, markedly dissonant because he refused to adhere to any single societal norm or musical convention. Dissonance as an embodied form compels us to think about how disruption can function as a model for critical practice. Further, musical dissonance has a tradition, especially within Bebop and Hip Hop that reflects the African American experience, ${ }^{21}$ with as much claim to critical fecundity and innovative distinctiveness as any of the other supposedly more valid systems of critical praxis often supported in academic institutions.

In Landing on the Wrong Note, Ajay Heble argues that "oppression, after all, is itself a space of dissonance, for it means being out of tune with naturalized assumptions about social structures and categories" (20). For example, Duke Ellington would explain after playing a dissonant chord on the piano, "Hear that chord. That's us. Dissonance is 
our way of life in America. We are something apart, yet an integral part" (qtd. in Ulanov 276). It is this element of oppression and controlled dissonance, as articulated in the above quotes, that makes the connection between the priorities of Bebop and Hip Hop particularly apt. While the connection between Monk and modern Hip Hop innovation is not always critically acknowledged, it helps to flesh out a critical aspect of improvisation: the moment when the music deviates from a standard-what Julia Kristeva terms the thetic phase: the moment which produces a positing of signification. For anything new to be created, a level of disruption must occur: something must be challenged, disrupted, contested, or grappled with. As Houston A. Baker Jr. argues, poetry, like rap, is intended to be a "disruptive performance [...] as an audible or sounding space of opposition" (Rap 96). While this audible sounding of opposition might read as negatively charged, for it is charged with a degree of negative capability ${ }^{22}$ (or, if we prefer, a level of negative pedagogy), this oppositional sounding finds creative potential in uncertainty, creating something "new," although not ascertainably definable, out of something old (from the archives of tradition).

While it might seem odd to attribute modernist/enlightened tendencies to the playing of Monk and his post or African American modern contemporaries, given the problematics of Ezra Pound (often considered the father of modernism) and his particularly anti-Semitic Pisan Cantos, it highlights that aesthetic innovation is by no means a European invention; ${ }^{23}$ rather, aesthetic innovation takes place within any cultural context on the basis of changing artistic and cultural circumstances, philosophies, and needs, often with a high level of confluence between cultures and traditions. While Monk certainly flaunts classical and jazz norms, like Ellington before him, his stylized playing also breaks away from previously defined traditions while still relying on their forms to create new ways of playing and approaching rhythm, in a sense, of making it new, being, as André Hodeir has said, "the first jazzman who has had a feeling for specifically modern aesthetic values" (qtd. in Reader 226). We see similar arguments made about many of Monk's contemporaries, and few, given his mass popularity, have caused more critical fervor than Miles Davis's approach to making it new. ${ }^{24}$ In the liner notes of Davis's Bitches Brew, Ralph Gleason argues, "electric music is the music of this culture and in the breaking away (not breaking down) from previously assumed forms a new kind of music is emerging." In this way, Davis's fusion-jazz albums, and Monk's more traditional yet still innovatively unique and dissonant albums, participate in a mastery of tradition (or multiple traditions) to create a discursive modernism that allows Black artists to maintain heteroglot identities and navigate more open modes of playing jazz. Houston A. Baker Jr. suggests that "The blending . . . of class and mass-poetic mastery discovered as a function of deformative folk sound-constitutes the essence of black discursive modernism" (Modernism 93). Exemplary of Baker's concept of Black modernism, Monk's music is particularly interesting in its ability to meld and find intersections with Western and African diasporic aesthetic canons and practices, what we might want to call (to borrow from Baker) "afromodernism." 25

"Afro-modernism," or what Weheliye terms "sonic Afro-modernity," "envelops both temporally and conceptually any putative original" (6). Essentially, as Weheliye argues: "no Western modernity without (sonic) blackness and no blackness in the absence of modernity" (45). Hence, Weheliye contends that modernity involves cultural and sonic confluences between sound, sight, or text, investigating the various vicissitudes between these spheres to "establish a dialogue between literary texts and current popular culture to conjecture how sonic technologies and black cultural production have fruitfully contaminated each other" (8). Thus, Black cultural practitioners, from Thelonious Monk to the Hip Hop group, Wu-Tang, are innovative contributors to Western modernity, responding as Ramsey argues, "to the experience of modernity" (97). These responses involve the "poetic mastery" of Black discursive modernism that Baker speaks of, primarily displayed sonically in music by artists who "fashion icons of opposition" (Lipsitz 99) by subverting or responding to previous standards, in a sense, remodernizing and "reshap[ing] the temporality of modernity" (Weheliye 144). Hip Hop practitioners, as Ramsey argues, "in true Afro-modernist fashion, have resisted some of the parameters set by the 'standard' musical system and have created a new approach that is pushed so close to the edge of established convention that even its status as music has been questioned" (192). Modernism, especially in popular culture, is constantly resounding itself in relation to the past artifacts, reversioning and redefining those archives. Most innovative jazz performances involve an act of molding something new out of something old, as jazz performers struggle to find their own unique voice within a polyphony of voices that came before, such as Coltrane's reimagining of "My Favorite Things," or to stretch the concept even further, in Wu-Tang's sampling and recontextualization of Monk's "Black and Tan Fantasy" in their song, "Shame on a Nigga."

\section{From BeBop to Hip Hop: Wu-Tang Clan's 36 Chambers}

The connection between Hip Hop and Bebop might be more commonly acknowledged, accepted, and put into praxis by jazz and Hip Hop musicians than mainstream jazz critics are aware. Guthrie P. Ramsey's central argument in Race Music: Black Cultures from Bebop to Hip-Hop is that if we consider the way in which jazz in the 1940s represented the quintessential Afro-modernist expression of Black urbanity, we will better understand how the musical styles most closely aligned with Hip Hop represent "the urban contemporary" for the current generation (187). Guru's Jazzmatazz projects, Madlib's remix album of the Blue Note catalogue, Shades of Blue, Quincy Jones's Back on the Block, Digable Planets' Reachin (A New Refutation of Time and Space), Miles Davis's final album, Doo- 
Bop, as well as the endless crates of jazz samples that are still used by popular artists such as Kanye West, are only some of the more popular examples that solidify the connection between jazz and Hip Hop. Hip Hop artist Nas's song "Bridging the Gap" is a great example of how Hip Hop absorbs and is indebted to prior African American musical forms. The track samples Muddy Waters's "Mannish Boy" and Nas's lyrics demonstrate an appreciation of the musical forms and artists that came before him: "Did it like Miles and Dizzy, now we gettin' busy/ Bridging The Gap from the blues, to jazz, to rap/ The history of music on this track." Even the Thelonious Monk Institute of Jazz runs a popular and successful program entitled "from BeBop to Hip Hop," which has featured Herbie Hancock working and playing with students, among many other well known jazz and Hip Hop artists. ${ }^{26}$ Hip Hop, as Weheliye argues, has come to define what "it means to be black and 'modern' within a global context and particularly in youth cultures" (146). For youth cultures around the world, Hip Hop helps define modern identities suspended between the local and global (the glocal); further, if we view Hip Hop as a dialogical mélange between prior African American musics, such as the blues and jazz, we can see how modernity is productively unstable: hence, a musical tradition can simultaneously adhere to the traditional as well as to the technological, improvising between multiple spheres of praxis through carefully nuanced techné.

Of course, there are many neoconservative jazz purists who maintain that forms of jazz fusion devalue and relegate jazz to the realm of the popular. Wynton Marsalis, who has tried to claim Monk as part of the conservative school of jazz, describes fusion in one interview "like rock itself. If you were there it was a great way to meet women and have a good time ... . but it's the death toll of jazz musicians" (qtd. in Solis 15). By contrast, rather than seeing an antinomy between Hip Hop and rock performances by Black musicians, Max Roach, a drummer who often performed and recorded with Monk, challenges simple divisions between genres, prioritizing Black artists as belonging to a unique African American tradition. In an interview with Frank Owen, Roach was asked how he felt about Black artists sampling from non-Black sources. Max Roach's argument is that the militancy is in the rhythm of Hip Hop. Roach argues, "Hip Hop swings. I never heard Led Zeppelin swing. Jesus Christ, now hip hop comes from Led Zeppelin, you motherfucker" (73). Additionally, given that Roach was one of Monk's drummers, his advocacy for Hip Hop artists as the new Charlie Parkers, because of their nonconformist ability to subvert an original, helps to strengthen my overall dialogic argument between jazz and Hip Hop music. Under the model of African American nonconformity, it is possible to see Hip Hop as a natural outgrowth from the resistive features inherent in jazz combined with the political and proto-rap aggression of Gil Scott-Heron and The Last Poets, among countless other musicians and genres.

Baraka states that current "rap is the continuum, certainly, of Rhythm and Blues, and the poetry of the real. Rap, as old as how we spoke across space, beating the log" (Digging 115). In a more outlandish, yet typically Barakian fashion, Baraka goes as far as to credit Monk as the inventor of breakdancing: saying "Each part of him would neon the rhythm: arms, knees, head, ducking, and spinning. Each beat would be highlighted by some part of him registering it" (230). ${ }^{27}$ Like the protagonist of Ellison's Invisible Man, Monk wants to "feel the [music's] vibration, not only with [his] ears but with [his] whole body" (8). In removing Hip Hop from the sole grips of postmodern production, Baraka highlights that the core priorities of Hip Hop and its use of repetition belong to an African continuum; however, we must acknowledge that Hip Hop's use of technology also situates it within a technologically defined North American oral-framework. ${ }^{28}$ So while Hip Hop and jazz certainly incorporate technology, it is important to remember, as Baraka reminds us, that the cultural priority of repetition (as old as the griot, the West African poet and historian) fits dialogically and culturally within an African continuum, functioning as circulation. In Black culture, repetition functions, as James Snead contests in "On Repetition in Black Culture," as circulation and equilibrium while in Western classical music, repetition is suppressed in favour of the final goal that lies in harmonic resolution:

In black culture, repetition means that the thing circulates, there is equilibrium [...] In European culture, repetition must be seen to be not just circulation and flow, but accumulation and growth [...] If there is a goal [in black culture] it is always deferred; it continually 'cuts' back to the start, in the musical meaning of a 'cut' as abrupt, seemingly unmotivated break (an accidental da capo) with a series already in progress and willed return to a prior series. $(150)^{29}$

It is important to acknowledge these cultural differences, not to affirm one as more artistically advanced, but to acknowledge that repetition, particularly as it has been articulated in African American culture, is not merely a manifestation (or simulacrum) of mass culture, as cultural theorists such as Theodor Adorno or Jacques Attali have argued.

In the age of mechanical reproduction, ${ }^{30}$ repetition is often viewed by cultural theorists as a byproduct of capitalism and a manifestation of sound reproduction, rather than perceived as part of African American aestheticism or as part of the continuum of modern poetic innovation. For instance, early in his career, Theodor Adorno describes the preswing jazz "break" as "nothing other than a disguised cadence [...] the cult of the machine which is represented by unabated jazz beats involves a self-renunciation that cannot take root in the form of a fluctuating uneasiness 
somewhere in the personality of the obedient" ("On Popular Music" 313). Wayde Compton, who is a turntable poet and critic, provides a poignant counterpoint to Adorno's antipopulist modernism, defending the function of repetition as a Black ontological priority in the creation of newness: "Repetition whether in the form of ancestor worship or the poem-histories of the griot, informs black ontologies more than does the Europeanist drive for perpetual innovation, with its concomitant disavowals of the past" (Bluesprint 17). Taking up these ontological priorities of repetition, DJs that carefully manipulate samples dialogically remap musical traditions and interrogate sub-imperialist notions of musical canonicity, and in the process create multiple planes of ambivalent listening through a disruptive practice of continual interpretation. What many hear as dissonant repetition in Hip Hop is in fact a site of potential racial disruption, revision, variation, disruptive dialogics, and "versioning": it is repetition, yet replete with difference, or as difference.

In this sense, many jazz and Hip Hop artists enact an improvisation from the margins of history to assert a poetics of dissent, difference, and disruption, empowering a shifting community that has been othered. This othering is creatively played out with empowerment in Wu-Tang's seminal album Enter the Wu-Tang (36 Chambers), which in my opinion is a relevant analogue to Monk's own reinterpretive practice, because it provided, despite critical antagonism, as did Monk's music, a foundation for what was to come on many subsequent albums by other musicians. ${ }^{31}$ Wu-Tang, in calling back to a non-conformist past of jazz, soul, and funk entertainers, is able to signify and riff upon past musical traditions with a distinctively new sound that doesn't so much as absorb another musical text as it dialogically engages with it. Unlike, though not adverse to, Julia Kristeva's highly popular notion of intertextuality, which views "Any text [as] constructed as a mosaic of quotations; any text is the absorption and transformation of another" (37), Hip Hop more closely aligns with Henry Louis Gates, Jr.'s depiction of intertextuality as an "ability to group together two lines that end in words that sound alike, that bear a phonetic similarity to each other" (The Signifying Monkey 61). Much of the sonic improvisation on 36 Chambers is the result of phonetic dialogism between sounds that mesh surprisingly well. RZA describes that he would start "sampling one note and playing it on different notes of the keyboard [. . .] chopping things down to notes and chords, not knowing which chords they were but knowing them as sounds" (197). It is this free rhythm and free style that help define the musical/linguistic aspect of Wu-Tang, influenced by African oral traditions of rhythmic talk-singing (signifying), recalling similar musical lines while also absorbing the entire gamut of popular culture.

The group's de facto leader RZA, produced the album with heavy, eerie beats and a sound largely based on martialarts movie clips and soul music samples, ensuring that the samples dialogically speak to one another. ${ }^{32} \mathrm{RZA}$ describes the sampler as "a tool and musical instrument" (190) that allows for improvisation largely based on the limitations of the technology at the time, aiding in the creation of dissonant, sparse, and unique sonic productions: "It couldn't be in tune because they didn't have the time-stretch back then [ . . ] I just thought it sounded dope that way. That's the other lesson: The limitations of technology can become the artistic tools themselves" (191). The distinctive sound of Enter the Wu-Tang (36 Chambers) created a blueprint for hardcore Hip Hop during the 1990s. Its distinctive sound also became hugely influential in modern Hip Hop production, while the group members' explicit, humorous, free-associative lyrics have served as a template for many Hip Hop artists. The caustic and bizarre humour (which is hardly unfamiliar in jazz: listen to Monk's "Humph"), theatrical personalities, cerebral storytelling, and the variety of lyrical technicians contribute to crafting an album that is full of play: martial arts metaphors, an unlimited supply of pop culture references, and a hyperbolic approach to lyrical violence are negotiated as different emcees trade off verses.

In fact, the collective, primarily made up of nine different emcees ${ }^{33}$ with rhizomatic offshoots that extend the Wu family into hundreds of collaborators worldwide, creates a type of improvisation that is co-opted as a social practice that negotiates disruptive performance within a community of difference. This community of difference is one that extends deep into the jazz and funk worlds, where collectives work together (such as Sun Ra and his Arkestra, Parliament, and many others) not only to make music, but to employ music as a form of social organization and oppositional struggle, finding strength in the power of the collective community. As Lipsitz argues in Footsteps in the Dark, "The collective memory at the heart of hip hop contains a material memory of the racial and generational dimensions of deindustrialization that would otherwise have remained hidden from history" (179). In this way, Hip Hop collectives (take note that Wu-Tang Clan is one of the first and perhaps only Hip Hop collective of its size) respond to the history of oppression through a history of resistance, drawing inspiration from a variety of genres and influences, which for Wu-Tang includes Asian martial arts and philosophical traditions that align their resistance against racism and mistreatment in opposition to a silencing that is both national and global in scope. Further, the many jazz and soul samples that the group's leader and producer RZA recontextualizes in his productions connect to Monk's own virtuosic ability to mix multiple styles within a single performance.

It is precisely, albeit hardly exclusively, Monk's dissonant, unique improvisatory style that was emulated and adapted under the collective of a nine-member group for Wu-Tang's seminal album 36 Chambers. RZA describes the process of creating the sound on the album as belonging to a tradition pioneered by jazz pianists such as Monk and Bill Evans. He says: 
I know that a sound I became known for at the beginning was that detuned acoustic piano zitherthose creepy notes that quiver in the air. It's the kind of sound you hear in ' $7^{\text {th }}$ Chamber,' 'Da Mystery of Chessboxin,' and a bunch of other joints. It's funny when people ask me the inspiration for it, because, to be honest, it was jazz pianists-mostly Bill Evans and Thelonious Monk-but the fact is I played most of it myself. (Wu-Tang Manual 191)

The Monk sample (or riff), from his version of "Black and Tan Fantasy" ${ }^{34}$ in "Shame on a Nigga" is not actually detuned, but does provide a rhythmically dissonant layering that simultaneously ruptures and revises the original with a wholly new life. As Gates argues, "The jazz riff is a central component of jazz improvisation and Signifyin(g) and serves as an especially appropriate synonym for troping and revision" (105). RZA describes taking sounds that sounded good to his ear and putting them together that way: mixing, chopping and revising riffs, even though they "were probably disharmonized and not in sync, but I could feel how they should fit as a whole" (204). The subtle incorporation of the riff from "Black and Tan Fantasy" in "Shame on a Nigga" emphasizes the group's desire to be seen as 'other' within the context of Black marginality, using Monk's idiosyncratic persona and playing as an aesthetic layering that furthers the heteroglot nature of the song to create what Rose describes in Hip Hop as "counterdominant narratives against a mobile and shifting enemy ... fortify[ing] a community of resistance" (Noise 61).

The song itself employs a complex polyphonic layering and rupturing dialogue: the "Black and Tan Fantasy" sample is layered in conjunction with a more funk-oriented horn sample from "Different Strokes" by Sly Johnson as three of the group's members (Raekwon, Ol' Dirty Bastard, and Method Man) take turns rapping hyperbolic, bravadoic and violent lyrics that dare others to contest with their style. Given the potentially alienating rhetoric and explicit lyrics, the song is exclusionary for many of its listeners; yet, I think it can also be read as a sounding of opposition formed in relation to those that would try to appropriate their style, thwart their mobility and ultimately the freedom that such mobility affords them. While it might be hard for listeners (who are not part of the cultural milieu or the vicissitudes of Hip Hop culture) to hear a sense of freedom in the song, it should be easier to grasp that the emcees are testing the limits of how identity is performed. Within this framework of spontaneous identity, the members of Wu-Tang Clan improvise by working together to craft a sound that is oppositional to prior structures of what is considered viable and commercial music, creating much of the album outside the conduit of a record deal ${ }^{35}$ (although the album certainly garnered them one) to enact collective mobility. George E. Lewis, in his assessment of philosopher Vladimir Jankelevitch's 1950's work on improvisation concludes that "improvisation becomes not so much a practice, but an aspiration toward freedom, that, even as it is doomed to failure, nonetheless produces a consciousness that continually transgresses limits and resists their imposition" ("Mobilitas" 120). In this sense, improvisation as a mode of thought that aspires towards a mobility of freedom (aesthetic and cultural) is clearly displayed in each member's unique performance, particularly in Ol' Dirty Bastard's scat-like poetics, which rupture the lines of audibility.

In "Shame on a Nigga," Ol' Dirty Bastard ${ }^{36}$ —who was by far the most eccentric member in the group, before his drugrelated death-provides the most explosive, and obscure verse in the song (coming in at 1:48 with the Monk piano loop), declaring: "Here comes the Tiger verse Crane!/ Owww, be wild with my style." His eccentric style of rapping, and use of obfuscation often baffled critics and fans alike much in the way that Monk's own eccentricities did. ODB's scat-like performance provides an ideal analogue to Monk's own spontaneity in both his style of playing and public narrative. As Baraka argues "The scat is the cultural memory of African languages, so essential in its fundamental powering of the music (Black Speech!) that it demonstrates it exists without and before American lyrics" (Digging 227). Like a typical jazz improviser, ODB uses the beat as the backdrop and his voice as an instrument to solo over the song. In many ways ODB is the perfect analogue to Monk, spontaneous and unpredictable, yet you can learn to expect one thing: the unexpected. RZA's incorporation of Monk's interpretation of "Black and Tan Fantasy" in "Shame on a Nigga" further emphasizes the group's desire to be seen as 'other' within the context of Black marginality, using Monk as a layering that speaks antiphonically to a disrupted community of young African American (though not exclusively) listeners.

Rappers and DJs use datums to speak to those who are part of Hip Hop's cultural literacy, using samples as tactics that define space. In this sense, improvisation and style are aligned in the quest for self-expression and representation. Heble maintains that "[i]mprovisation is a powerful ally in struggles for self-expression, selfdetermination, and self-representation" (93). Heble's standpoint is supported by Ralph Ellison who argues that "the jazz man must lose his identity even as he finds it" (Shadow and Act 234), suggesting that Black identity, or any identity formed within improvising principles, is in a process of continual formation. In creating a disruptive poetics, Wu-Tang and Thelonious Monk subvert the harmonic lexicon of standardized musical practice-often alienating listeners in the process-by presenting their music in a way that is bewildering to untrained or outside listeners. 


\section{The task of the listener}

Perhaps an ethics of listening must involve a level of dialogic disruption: the music of Monk and Wu-Tang challenges us to bend our listening approaches, to recognize that which has been labeled as 'other,' and to consider the cultural priorities, matrixes, and complexities of such music. Monk inspired a whole range of jazz artists, from Bud Powell, to Parker and Gillespie, to Miles Davis who said that "Monk has been a big influence in giving musicians more freedom [. . .] Monk has been using space for a long time" (qtd. in Reader 209). Indirectly, Monk has also inspired a wide variety of Hip Hop producers who want to emulate the polyrhythms of his playing, and emcees who want to use his style and persona to help craft their own fictions against an often oppressive world for young African American youths. For example, RZA describes the freedom his own playing garnered after watching the film Straight No Chaser and seeing Monk smoke a cigarette, smack the piano, walk away and come back, leading him to assert that you "'can do anything! There's no rules to it!' [ . . . After I saw that movie I started playing around with the piano part in 'Chessboxin' [ . . . That's all from me watching Thelonious Monk with a joint in my hand, just playing” (191).

Listening for freedom is about learning how to listen particularly to those sounds that society often labels as "noise" because they sound dissonant, are often political, or disruptive to the dominant social order. Even though, beginning with Plato, music was thought to have no significance without the accompaniment of words (Weheliye 10), the music of Thelonious Monk, and countless other musicians, reminds us, as Baraka argues, that "Ideas do not require lyrics! Sound carries ideas, that's why you get sad at one song, happy with another" (Digging, "Black Music as a Force for Social Change" 102). Good music, like good writing, inspires other artists to cover their own version(s) of a song, to actively listen and to respond. Listening itself, as George E. Lewis argues, is "an improvisation act engaged in by everyone, [announcing] a practice of active engagement with the world" (113). This is the important part: instead of being mere passive listeners, or voyeurs of the popular, we can, as scholars and cultural enthusiasts, use listening (as a type of cultural criticism) as an agent for change. In the words of bell hooks, "cultural criticism can be and is a vital location for the exchange of knowledge, or the formation of new epistemologies" (Outlaw 7). It depends on the type of listening we do, not merely as individuals, but as a collective listenership in dialogue.

Hip Hop creates dialogism that participates in an ongoing deconstructive and reconstructive process, vis-à-vis sampling and intertextual references that function as types of antiphonic signification that incorporate a listener. Bakhtin describes the role of the listener as quintessential to the functionality of all human speech: "every word is directed toward an answer and cannot escape the profound influence of the answering word it anticipates" (280). The chorus in Hip Hop, the repetition or recognizable sounds of a jazz composition, as it is with most popular genres of music, is a moment that brings the audience together in collective solidarity, encouraging them to participate: to improvise its meaning. As Dick Hebdige argues, the collective nature of improvisation "calls into question the myths of individual agency and innovation-in-isolation on which the dominant Western understandings or artistic productions are founded ("Even Unto Death" 337). While Hebdige is not so much dismissing the role of individual mastery or creativity, he is reminding us that performance, particularly that involving improvisation, exists on a level beyond the performer; improvisation, and its manifold connotations, enters into a larger intricate social network that encourages dialogue, even if it enacts disruption - in fact, probably more ideally so if a particular performance's disruption, upon its unfinished completion, causes us to go out in the world and perform its meaning.

Whether the new listener is the dial-twiddler (the one performing the performance of the performance) that Glenn Gould has in mind in his "Prospects of Recording," the DJ, the person walking down the street listening to his or her iPod, or a collective of people listening to a live performance (which does still happen), the dialogic nature of music is irrefutable, yet the types of dialogues we should be forming are multitudinous and open to scrutiny. We live in a world where pop music has become more commoditized than ever and where sampling is often an act negotiated by corporations and decided by monetary values rather than viewed as artistic endeavors produced in dialogue. The music of Thelonious Monk and Wu-Tang Clan's 36 Chambers reminds us that listening does not have to be a passive act: disruption is a pedagogy that promotes social change and forces us to recognize the often exclusionary practice of what is considered proper music. As Cecil Taylor notes: "It seems to me that in the long run your art becomes a reflection of a consciousness which, if it is powerful enough, may change the social consciousness of the people who listen to you. Great music implies a challenge to the existing order" (qtd. in Willener 255). Taylor's assessment of art seems to coincide with Monk's impression of what Jazz represents in its capacity to create space. When asked about Jazz, Monk said, "It's about freedom, more than that is complicated" (qtd. in Baraka, Digging 27). While our approaches and relation to technology as a tool to make music change over time and while our approaches to forming communities change, Taylor reminds us that what is most important about art is not just its power to question existing orders solely by the artist, but more crucially how art functions within the role of the listener who goes out in the world and continues to enact its meaning - searching for the evidence the music speaks by enacting its freedom. 
Monk truly spoke that freedom in his music, as demonstrated in his composition "Evidence," which is dialogically built upon the chord changes to the Klages and Greer standard "Just You, Just Me," which from there Monk educed "Just Us" (see Kelley 114; 564). Phonetically, it does not take much to move from "Just Us" to "Justice," under which title Monk's "Evidence" was recorded several times. However, for Monk, and for us as listeners ethically grounded in the potential of audio interplay in relation to social justice, there can be no "Justice" without "Evidence"-signifying the final name of Monk's composition. Here, Monk embodies the power and focus of recontextualization, reminding us that at some point art and politics are sometimes hard, if not impossible, to separate; vice-versa, musical genres and categories are impossible to label cohesively, especially given the human capacity for constant improvisation. In his essay, "Turntable Poetry, Mixed-Race, and Schizophonophilia," Compton describes "schizophonophilia" as the "Iove of audio interplay, the pleasure of critical disruptions to natural audition, the counter-hegemonic affirmation that can be achieved through acoustic intervention" (199). I like the notion of acoustic intervention, the notion of disrupting the pretense of naturalism, as a reminder that democracy (as embodied in sound) is itself most effective when it is its most discordantly free.

As Fred Moten argues in In the Break, "This is about the importance, which is to say the politics, of how you sound" (222-223). Thelonious Monk and the Wu-Tang Clan are but two examples of artists daring to sound their sonic freedoms through their love of audio-interplay, which is really an interplay between the self and the community of musicians and listeners fortified in the quest for greater artistic and human freedom. I can say with assurance that jazz (and its many dialogic offshoots) still has a strong role to play for many artists who use sampling as a way to dialogically situate themselves and their listeners in a subversive musical and political past that promotes a present sense of a community in dialogue, and often without any script, against the backdrop of an often hegemonic recording industry. Ideally, this is a community formed not only for and by music artists, because in the end it's all about us, reverberating Monk's sentiment in "Evidence," as street-preacher and albino rapper Brother Ali heralds: "cause can't nobody be free unless we're all free/ there's no me and no you it's just us" ("Us").

\title{
(re)vision \& the abstract truth
}

\author{
sound played \\ begun, spun \\ delayed \& reverberated \\ from the womb, our first ear \\ to the tomb our final crescendo \\ $\sim$ with liner notes \\ sampling is abstract history \\ history is sampling made abstract \\ $\&$ revision is life remixed \\ to the percussive ebbs of sound waves
}

music is:

more praxis than practice

more active than passive

more the work of the blacksmith

less:

the work of the mathematic

although rhythm is meticulously enacted

off/time

on/time

all-the-time

the motion is the rupture

the line is the rhyme

conductor, conductor

instructor, within structure

interconnected by time improvised with the kinetics

of the tidalectics ${ }^{37}$

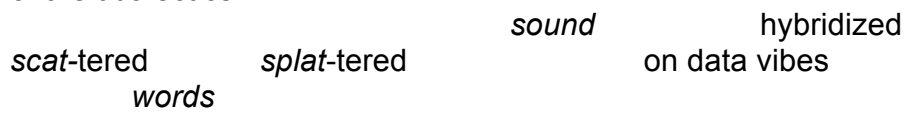




\author{
the needle in the groove \\ (the sample on the left) (the a cappella on the right) \\ the tactile metaphor moves \\ the body, the machine in flight
}

technoculture, counterculture, subculture, cyberculture, my culture, your culture

swingin' colonial institutions back into primal sound animals

Derrida couldn't improvise with Ornette Coleman ${ }^{38}$

(he was booed)

\& Marsalis couldn't improvise with Miles

cause Miles thought Marsalis was rude ${ }^{39}$

\& come on,

Marsalis could never groove with Miles's

blue mood

we need to relearn listening

before our logic was anthropologic \& anthropocentric

we were arthropods banging together a rock \& a log

dancing around the fire

so let's move between

the in-between

as cybernetic organisms whose improvisations are microscopic

beyond the range of the telescopic lens,

$\&$ let the conscious bend

$\&$ once again listen in:

'till ears are made dizzy from Gillespie infused epilepsy

$\&$ behold Gould humming manifold notes in tongue

listen,'till Adorno's work on jazz culture reads like homemade porno

feel the music in being:

like Thelonious gyrating the rhythm with his body

like Jacqueline du Pré turning Elgar into the cello's telepathy

like Robert Johnson picking his strings so masterfully

like Ornette Coleman shaping our soul man

like Sid Vicious redefining rock \& roll

like Skaay using words to make a blue raven fly ${ }^{40}$

like Beethoven breaking the $\mathrm{m} /$ old with his final (oh)d

like Hendrix turning the guitar into an appendage

like Mingus picking the bass with such nimble fingers

like Elvis and his pelvis making teenagers cum

with Grand Wizard Theodor

back for more

making ya'll hit the dance floor in a flash

like Grand Master Flash with the innovative scratch

(re)inscribing sound

from the banging of a body

to the banging of a drum

from the womb where your mother's beating heart was the first tune

you listened to

to you,

the maker of sound

however profound, or unsound, it's still your voice 
enacted \& abstracted

it's the abstract truth as we improvise our daily lives trying to harmonize while we collide with disruptive tides

Written, recorded, and performed by Paul Watkins.

\section{Notes}

${ }^{1}$ Full text of "(re)vision \& the abstract truth" reprinted at the end of this paper.

${ }^{2}$ While I choose not to capitalize any of the musical genres (because they are not proper nouns) it might seem a little slippery that I capitalize Hip Hop. The reason for this is not that I think Hip Hop deserves capitalization over other genres; rather, I use the capitalization to refer to the larger culture that encompasses Hip Hop; whereas if I were to talk about pop music or rap music, I would be referring to their generic categories. Hip Hop music is a secondary oral subculture that is made up of five primary elements: Hip Hop dance (notably break dancing), urban inspired art (markedly graffiti), deejaying (turntablism), beatboxing and emceeing (rapping).

${ }^{3}$ In fact, this is one of the central arguments Rob Wallace posits in his exploration of the American modernists' use of improvisation in his book, Improvisation and the Making of American Literary Modernism.

${ }^{4}$ For further clarity, Weheliye describes breaks, or breakbeats, as "the moment of old funk and r\&b recordings where the melody disappears and is replaced by the rhythmic solo" (87).

${ }^{5}$ It should also be acknowledged that there have always been many supporters, both white and Black, in academia and musical circles alike, who have maintained the pedagogical efficacy and musical complexities of Bebop and Hip Hop. Of course, the history of American popular music is more complicated than white musicians stealing the music of black innovators, as Robin D. G. Kelley argues: "The history of American popular music is often depicted as a series of stories of white musicians imitating black innovators and getting rich, from Benny Goodman to Elvis to Eminem" (58). Kelley goes on to mention how many critics and fans applauded Goodman's choice to incorporate black musicians into his band, such as Fletcher Henderson, Teddy Wilson, Lionel Hampton and Charlie Christian, calling this move an example of integration (58). However, Kelley also reminds his readers that for Black musicians, "it seemed more like 'raiding' their most talented and dynamic musicians" (58).

${ }^{6}$ In this way, Hip Hop aptly conjoins to early critiques of Bebop (such as negative reviews of Thelonious Monk's music) in jazz magazines such Down Beat, which described the music as dissonant noise without structure. The April 21, 1948 issue of Down Beat describes Monk's "Round About Midnight" as "for the super hip alone. Why they list the personnel on a side where the whole band plays like a vibratoless organ under the piano solo is a mystery" (19).

${ }^{7}$ By using the tools of the oppressors, particularly recording technology (a technology that has historically been controlled by executives at recording labels to sell a product via an industry that has typically commoditized and often appropriated African American music), many African American Hip Hop groups reinscribe their voices within an empire that attempted to historically control them. Many Hip Hop groups, such as Public Enemy, Dead Prez, and WuTang, reappropriate the technology in the same way that the early do-it-yourself Hip Hop deejays appropriated the turntable to create music from the archives of the past that reflects the cultural landscape of the present. This is not to dodge the reality that Hip Hop music has become commodified by large corporations and marketed to mostly suburban white audiences, but it is merely to suggest that there are many Hip Hop groups who are interested in a music that abrogates against oppression in a similar vein enacted in Hip Hop's street-level inception.

${ }^{8}$ Michel de Certeau defines tactics as belonging to the "other," which can indicate that rappers who use English, changing its intonations and meanings through grammatical reformation, are actually participating in a semiotic form of resistance: "A space of a tactic is the space of the other . . . play on and with a terrain imposed on it ... tactic is an art of the weak" (Practice of Everyday Life 37). Rappers and DJs use datums to speak to those who are part of Hip Hop's cultural literacy, using samples as tactics that define space, as old school rap group Stetsasonic claims: "You 
see, you misunderstood/ A sample is just a tactic,/ A portion of my method, a tool" ("Taking all that Jazz").

${ }^{9}$ In this paper I use the playing and idiosyncrasies of Monk's persona as an ideal model for critical interpretations of how freedom functions in jazz; however, there are countless jazz musicians and collectives, such as Sun Ra, The Art Ensemble of Chicago, Cecil Taylor, John Coltrane, Ornette Coleman and Charles Mingus, just to name a few, who would also serve as ideal models for this type of trajectory practice. Monk is also an interesting figure because he very rarely expressed his political views, but rather spoke them, as I hear it, through his playing.

${ }^{10}$ There is a plethora of poetry written about Monk, far too much to mention in any detail here, certainly enough to fill an entire anthology. However, some key poets who have written on Monk and who have tried to capture his style of playing in their own dissonant poetics, include: Amiri Baraka, Charles Simic, Michael Harper, Yusef Komunyakaa, William Corbett, Al Young, Dave Etter's book Well you Needn't, and Art Lange's The Monk Poems, among others.

${ }^{11}$ Grover Sales, in an article for Jazz, describes Monk as unique, because "he seems to be influenced by everyone and no one in particular."

${ }^{12}$ According to biographer Kelley, the 1964 Time appearance came because "Barry Farrell, who wrote the cover story, wanted to write about a jazz musician and almost by default Monk was chosen, because they thought Ray Charles and Miles Davis were too controversial, whereas Monk wasn't so political" (342). Kelley, in the biography, challenges the viewpoint that Monk wasn't political, arguing that he in fact left behind a political legacy in his music.

${ }^{13}$ Ingrid Monson argues that, "Monk's reluctance to verbalize-to interviewers, musicians seeking instruction, and even friends and family members-provides further evidence that music was his true language. Monk spoke the unspeakable through music and took the listener to 'another level' through his utterly original compositions and improvisation" ("Monk Meets SNCC" 1).

${ }^{14}$ This is the same argument that Aldon Lynn Nielsen makes in Black Chant in regards to critics of avant-garde poetry, whom he argues "seldom look at black writers while compiling their genealogies of aesthetic evolution" (13). Further, see Tricia Rose's Black Noise, and her more recently published The Hip Hop Wars, which examines how many conservatives and academics uncritically profile Hip Hop artists and fans of all genders, races, and classes (25).

${ }^{15}$ For clarification, it should be noted that I use the word dissonance, which Grove Music online defines as "The antonym to consonance, hence a discordant sounding together of two or more notes perceived as having 'roughness' or "tonal tension." The Oxford Dictionary of Music redirects me from dissonance to "discord," which is described as: "A chord which is restless, jarring to the ear, requiring to be resolved in a particular way if its presence is to be justified by the ear." While these definitions are rather vague, it should also be noted that when Monk plays certain chords or rhythms, they might be perfectly suited rhythmically or melodically within the theoretical context of a composition. Nevertheless, they might still be considered dissonant because of the jarring percussive attack of Monk's playing, certainly unique at the time. This is undeniably somewhat different in Hip Hop music where a group of samples in different keys are layered together; nevertheless, the effect can still be jarring, while making perfect musical sense within the datums of that musical practice. I use dissonance not as a negative term to describe something sounding un-musical, so much as to highlight that dissonance, particularly as a metaphor, provides valuable musical nodes to rescripting standard Western notions of harmony and rhythm.

${ }^{16}$ Also, see Down Beat (June 17th, 1949,) where Monk's now lauded classic "Misterioso" is described as "veritably faking" (14).

${ }^{17}$ Bill Evans was another supporter of Monk's technical proficiency on the piano. In the liner notes to Monk, Evans defends Monk's ability to play the piano in a manner that is both technical and unique, saying: "Make no mistake. This man knows exactly what he is doing in a theoretical way . . Monk approaches the piano and, I should say right now, music as well, from an 'angle' that, although unprecedented, is just the right 'angle' for him." Evans's sentiment is reflected in Gang Starr's song, "Jazz Thing," where Guru raps in regard to Monk that "No mistakes were made with the notes he played." 
${ }^{18}$ The documentary film, Thelonious Monk: Straight, No Chaser, uses footage taken from 14 hours of European concert performances filmed in 1967-68 by Christian Blackwood. The video recording of "Just a Gigolo" begins around $32: 30$ in the film.

${ }^{19}$ In A Thousand Plateaus, Deleuze and Guattari make the claim that "meter is dogmatic, but rhythm is critical" (313).

${ }^{20}$ See Brown, "More Man than Myth, Monk Has Emerged from the Shadows," 13.

${ }^{21}$ See Amiri Baraka's Blues People and Ajay Heble's Landing on the Wrong Note. Further, the cross-culturality of a disruptive practice in writing is explored by Nathaniel Mackey in his work Discrepant Engagement, which highlights African American and Caribbean writers' valorization of dissonance, divergence and formal disruption.

${ }^{22}$ The concept of negative capability comes from poet John Keats. It is a theory that describes the capacity for accepting uncertainty and irresolution in life.

${ }^{23}$ For example, Baraka, in engaging with Pound, argues that Pound's poetic dictum, to make it new, is ontologically African: "Make it New attributed to Ezra Pound is Eastern. It is the African (and Sufi) explanation of why life, even though contained by an endless cycle, or not contained, is an endless cycle can be, is worthwhile, ie. make it new and lo and behold KARMA (digit???)" ("Notes" 46).

${ }^{24}$ Miles Davis, during one of his famous recording sessions, which produced most of the album Bag's Groove, did not let Thelonious Monk accompany him during one of his solos. Interestingly, and showing just how unconventional Monk's playing was, Davis found Monk's idiosyncratic accompaniment style difficult to improvise over and asked him not to accompany him. In some accounts, this nearly brought them to physical blows. According to Davis in his Autobiography, Davis asked Monk to "lay out [. . . ] because Monk never did know how to play behind a horn player" (187). Davis goes on to say that he told Monk to come in a little after he plays and that there wasn't any argument: "I don't know how that story got started about me and Monk arguing so bad we almost came to blows" (187).

${ }^{25}$ See Guthrie P. Ramsey, Race Music: Black Cultures from Bebop to Hip-Hop (Berkeley: University of California Press, 2003) in which Ramsey discusses the idea of Afro-Modernism at length by exploring Black music in the Twentieth Century as dialogically constituted in an ongoing vibrant musical community; also, see Craig Hansen Werner, Playing the Changes: From Afro-Modernism to the Jazz Impulse (Urbana: U of Illinois Press, 1994), which explores the complex exchanges between European and American (postmodernisms) and African American Culture; lastly, see Alexander G. Weheliye, Phonographies: Grooves in Sonic Afro-Modernity (Durham: Duke University Press, 2005), which examines the multiple links between Black cultural production and sound technologies through an intervention that rejects assessing sonic modernity and visual modernity as diametrical opposites.

${ }^{26}$ Interestingly, Monk's own son, T.S. Monk, is an ardent supporter and believer in the connection between jazz (particularly Bebop) and Hip Hop. I recommend going to the Institute's website and checking out the promotional video for this program: http://www.monkinstitute.org/education/beboptohiphop/

${ }^{27}$ To see an example of what Baraka is referring to check out Monk diggin' and grooving to the sax solo in "Evidence" (from Straight, No Chaser) from 0:20-1:05. Further, Monk's penchant for dancing is documented in Charles Mingus' autobiography, Beneath the Underdog, where Monk's dancing is described at a party during a dance competition between Monk and Baby Lawerence $(287,292)$.

${ }^{28}$ Rose argues that "to interpret rap as a direct or natural outgrowth of oral African-American forms is to romanticize and decontextualize rap as a cultural form" (95). While Hip Hop music certainly incorporates forms of oral storytelling, it is also infused with and informed by modern technology: "rap simultaneously makes technology oral and technologizes orality" (Rose 86).

${ }^{29}$ This sentiment regarding the difference between the repetitions of African music and European classical music is also reflected in Christopher Small's Music, Society, Education, where he argues that "The repetitions of African music have a function in time which is the reverse of (Western classical) music-to dissolve the past and the future 
into one eternal present, in which the passing of time is no longer noticed" (9-10). Also, see Charles Mingus's autobiography, Beneath the Underdog, where he describes "rotary perception" as a beat existing within a circle, which allows for greater improvisation: "imagine a circle surrounding each beat-each guy can play his notes anywhere in that circle and it gives him more free space" (350-351).

${ }^{30}$ See Walter Benjamin's "The Work of Art" where he argues that mechanical reproductions are autonomous of the original ("Mechanical reproduction of a work of art, however, represents something new" (218)), and that mechanical reproductions can be understood in a context the original is unable to reach.

${ }^{31}$ Like Monk's own work, 36 Chambers initially met with critics who fell on two diametric sides, loving or criticizing the album for its aesthetic innovations; while insisting the album was not a complete failure, Robert Christgau warned listeners that if you "Expect the masterwork this album's reputation suggests [you'll] probably be disappointed-it will speak directly only to indigenous hip hoppers. Expect a glorious human mess."

${ }^{32}$ RZA describes that it is important to choose samples that fit within the themes and structures of a given song: "As far as dialogue samples from kung-fu flicks or crime movies. I'm also pretty careful. Sometimes, now and then, I'll hear a hip-hop joint throw in a sample of some AI Pacino shit and it sounds completely random. It doesn't have anything to do with the song itself" (192).

${ }^{33}$ Formed in New York City, the Wu-Tang Clan consists of RZA, GZA, Method Man, Raekwon, Ghostface Killah, Inspectah Deck, U-God, Masta Killa, and the late Ol' Dirty Bastard.

${ }^{34}$ Originally written by Duke Ellington and Bubber Miley.

${ }^{35}$ Initially Wu-Tang was part of the Tommy Boy roster, but the label made the decision to sign the all-white group, House of Pain instead. RZA describes that when his group was dropped he felt bamboozled, since they "'chose a bunch of whiteboy shit over me'" (73).

${ }^{36}$ According to the Wu-Tang Manual, the name Ol' Dirty Bastard (ODB) is a name that itself signifies improvisation, in that it suggests that "there ain't no father to his style" (10), and that "He's a true American free spirit" (12).

${ }^{37}$ Tidalectics is Kamu Brathwaite's term to describe an Africanist model for history; interplay between generations.

${ }^{38}$ Ornette Coleman, who had recently befriended philosopher Jacques Derrida, invited the philosopher to perform an improvised duet with him at the 1997 Paris Jazz Festival. Derrida's philosophical spoken-word piece was to accompany the free jazz playing of Coleman. While Coleman was playing Derrida came onto the stage and began to read his free-style philosophical piece. Within moments he was booed off the stage.

39 In Miles: The Autobiography, Miles Davis describes how Marsalis came unannounced onstage in the midst of his performance at the inaugural Vancouver International Jazz Festival in 1986. Marsalis apparently whispered into Davis's ear that he was told to do so; Davis responded by ordering him off the stage. Davis states, "Wynton thinks that music is about blowing people away up on stage. But music isn't about competition, but about cooperation, doing shit together and fitting in" (375).

40 Skaay was a blind Haida storyteller born circa 1827 at Qquuna. Skaay could neither read nor write, but his oral stories of Haida mythology have survived in the written transcriptions of anthropologist John Swanton. More recently, poet Robert Bringhurst retranslated Skaay's stories in the 2002 collection Being in Being: The Collected Works of a Master Haida Mythteller (Skaay of the Qquuna).

\section{Works Cited}

Adorno, Theodor, and George Simpson. "On Popular Music." On Record: Rock, Pop, and the Written Word. Ed. Simon Frith and Andrew Goodwin. New York: Pantheon, 1990. Print.

Ali, Brother. "Us." US. Rhymesayers Entertainment, 2009. CD. 
Attali, Jacques. Noise: The Political Economy of Music. Minneapolis: Minnesota UP, 1985. Print.

Baker, Jr., Houston A. Afro-American Poetics. London: Wisconsin UP, 1988. Print.

---. Blues, Ideology, and Afro-American Literature: A Vernacular Theory. Chicago: Chicago UP, 1984. Print.

---. Black Studies, Rap, and the Academy. Chicago: Chicago UP, 1993. Print.

---. Modernism and the Harlem Renaissance. Chicago: Chicago UP, 1987. Print.

Bakhtin, M. M. The Dialogic Imagination. Ed. Michael Holquist. Trans. Caryl Emerson and Micharl Holquist. Austin: UP Texas, 1981. Print.

Baraka, Amiri. Digging: The Afro-American Soul of American Classical Music. Berkeley: California UP, 2009. Print.

---. "Notes on Lou Donaldson \& Andrew Hill." Cricket (1969): 46. Print.

Benjamin, Walter. "The Work of Art in the Age of Mechanical Reproduction." Illuminations: Essays and Reflections. Ed. Leon Wieseltier. Trans. Harry Zohn. New York: Schocken Books, 2007. 217-251. Print.

Blackwood, Christian and Charlotte Mitchell Zwerin. Thelonious Monk: Straight, No Chaser. Warner Brothers, 1998. Film (Documentary).

Bliek, Rob Van der. The Thelonious Monk Reader. New York: Oxford, 2001. Print.

Brown, Frank London. "More Man than Myth, Monk Has Emerged from the Shadows." Down Beat 25 (1958): 13-16. Print.

Certeau, Michel de. The Practice of Everyday Life. London: UP California, 1984. Print.

Compton, Wayde. "Turntable Poetry, Mixed-Race, and Schizophonophilia." After Canaan: Essays on Race, Writing, and Region. Vancouver: Arsenal Pulp Press, 2010. 183-201. Print.

---. Bluesprint: Black British Columbian Literature and Orature. Vancouver: Arsenal Pulp, 2001. Print.

Christgau, Robert. "Consumer Guide: Enter the Wu-Tang (36 Chambers).” The Village Voice: 1993. Web. 15 June 2011.

Davis, Miles. Bitches Brew. Columbia. 1970. LP.

---. Kind of Blue. Columbia. 1958. LP.

Davis, Miles and Troupe, Quincy. Miles: The Autobiography. New York: Simon \& Schuster, 2011. Print.

Deleuze, Gilles, and Guattari, Felix. A Thousand Plateaus: Capitalism and Schizophrenia. Minneapolis: Minnesota UP, 1987. Print.

---. Difference and Repetition. Trans. Paul Patton. New York: Columbia UP, 1994. Print.

Down Beat. "Round About Midnight." April 21, 1948. 19. Print.

Ellison, Ralph. Invisible Man. New York: Vintage Internation Edition, 1995. Print. 
---. Shadow and Act. New York, Random House, 1964. Print.

Farrell, Barry. “The Lonliest Monk.” Time Magazine. 28. Feb. 1964. Web. 20 Nov. 2010. 1-10.

Feather, Leonard. Inside Be-Bop. New York: Da Capo, 1977. Print.

Gates, Jr., Henry Louis. The Signifying Monkey: A Theory of Afro-American Literary Criticism. New York: Oxford UP, 1988. Print.

Givan, Benjamin. “Thelonious Monk's Pianism.” The Journal of Musicology 26.3 (2009): 404-442. Print.

Gould, Glenn. "The Prospects of Recording." Audio Culture: Readings in Modern Music. Eds. Christopher Cox and Daniel Warner. New York: Continuum International, 2004. 115-126. Print.

Hebdige, Dick. Cut 'n' Mix. New York: Routledge, 2005. Print.

Heble, Ajay. Landing on the Wrong Note: Jazz, Dissonance, and Critical Practice. New York: Routledge, 2000. Print.

Hentoff, Nat. "Three Ways of Making It.” The Jazz Life. New York: DaCapo, 1975. 170-221. Print.

hooks, bell. Outlaw Culture: Resisting Representations. New York: Routledge, 1994. Print.

---. "Performance Practice as a Site of Opposition." Let's Get It On: The Politics of Black Performance. Ed. Catherine Ugwu. Seattle: Bay Press, 1995. 210-21. Print.

Kelley, Robin, D.G. Thelonious Monk: The Life and Times of an American Original. New York: Free Press, 2009. Print.

Kristeva, Julia. The Kristeva Reader. Ed. Toril Moi. Oxford: Blackwell, 1986. Print.

Lewis, George E. “Mobilitas Animi: Improvising Technologies, Intending Chance.” Parallax 13.4 (2007): 108-122. Print.

Lipsitz, George. Footsteps in the Dark: The Hidden Histories of Popular Music. Minneapolis: Minnesota UP, 2007. Print.

---. Time Passages: Collective Memory and American Popular Culture. Minnesota: Minnesota UP, 1990. Print.

Mackey, Nathaniel. Discrepant Engagement: Dissonance, Cross-Culturality and Experimental Writing. New York: Cambridge UP, 2009. Print.

Miller (DJ Spooky), Paul, and lyer, Vijay. "Improvising Digital Culture: A Conversation." Critical Studies in Improvisation / Études critiques en improvisation 5.1 (2009): 1-10. Web. 25 July 2011.

Mingus, Charles. Beneath the Underdog. Ed. Nel King. New York: Vintage Books, 1991. Print.

Monk, Thelonious. Monk. Liner Notes. Bill Evans. Columbia, 1965. LP.

---. Thelonious Monk Live at the It Club. Columbia, 1964. LP.

---. Thelonious Monk Plays Duke Ellington. Riverside, 1955. LP. 
Monson, Ingrid. “Monk Meets SNCC.” Black Music Research Journal 19.2 (1999): 186-200. Print.

Moten, Fred. In the Break: The Aesthetics of the Black Radical Tradition. Minneapolis: Minnesota UP, 2003. Print.

Nas. "Bridging the Gap." Street's Disciple. Sony Music, 2004. CD.

Nealon, Jeffery T. "Refraining, Becoming-Black: Repetition and Difference in Amiri Baraka's Blues People." Symplokē, Vol. 6. Special Issue: Practicing Deleuze \& Guattari (1998): 83-95. Web. 20 Nov. 2010.

Public Enemy. "Night of the Living Baseheads." It Takes a Nations of Millions to Hold Us Back." Def Jam. 1988. LP.

Ramsey, Guthrie P. Race Music: Black Cultures from Bebop to Hip-Hop. Berkeley: California UP, 2003. Print.

Roach, Max. “Hip Hop BeBop.” Interview by Frank Owen. Spin Oct. 4.7 (1998): 60-61, 73. Print.

Rose, Tricia. Black Noise: Rap Music and Black Culture in Contemporary America. London: Wesleyan UP, 2004. Print.

---. The Hip Hop Wars. New York: Basic Books, 2008. Print.

RZA. The Wu-Tang Manual. New York: Penguin, 2005. Print.

Sales, Grover. "I Wanted to Make It Better: Monk at the Black Hawk [sic]." Jazz: A Quarterly of American Music V.5 (1960): 31-41. Print.

Solis, Gabriel. Monk's Music: Thelonious Monk and Jazz History in the Making. California: California UP, 2008. Print.

Small, Christopher. Music, Society, Education. Hanover: Wesleyan UP, 1996. Print.

Snead, James A. "On Repetition in Black Culture." Black American Literature Forum 15.4 (1981): 146-54. Print.

Spivak, Gayatri Chakravorty. Outside in the Teaching Machine. London: Routledge, 1993. Print.

Stetsasonic. "Taking all that Jazz.” In Full Gear. Tommy Boy. 1988. CD.

Ulanov, Barry. Duke Ellington. New York: Da Capo, 1972. Print.

Wallace, Rob. Improvisation and the Making of Literary Modernism. New York: Continuum, 2010. Print.

Walser, Robert. "Rhyme, and Rhetoric in the Music of Public Enemy." Ethnomusicology 39.2 (1995): 193-217. Print.

Weheliye, Alexander. Phonographies: Grooves in Sonic Afro-Modernity. Durham: Duke UP, 2005. Print.

Willener, Alfred. The Action-Image of Society: On Cultural Politicization. Trans. A.M. Sheridan Smith. London: Tavistock, 1970. Print.

Wu-Tang Clan. Enter the Wu-Tang (36 Chambers). Loud, 1993. CD. 